\title{
Testicular Cancer pT4 TNM Finding v8
}

National Cancer Institute

\section{Source}

National Cancer Institute. Testicular Cancer pT4 TNM Finding v8. NCI Thesaurus. Code C140218.

Testicular cancer in which the tumor invades scrotum with or without lymphovascular invasion. (from AJCC 8th Ed.) 